\title{
Effect of Organic Manuring Practices on Growth and Yield of Palak (Beta vulgaris var. bengalensis Hort.)
}

\author{
P. Irene Vethamoni ${ }^{1 *}$ and Syama S. Thampi ${ }^{2}$
}

Horticulture, RVS Padmavathy College of Horticulture, Sempatti, Dindigul, Affiliated to Tamil Nadu Agricultural University, Coimbatore - 641003

*Corresponding author

\section{A B S T R A C T}

\begin{tabular}{|l|}
\hline Keyw or d s \\
Vermicompost, \\
Farmyard manure, \\
Palak, Foliarspray, \\
Organic manures \\
\hline Article Info \\
\hline Accepted: \\
12 July 2018 \\
Available Online: \\
10 August 2018 \\
\hline \hline
\end{tabular}

Field experiments were conducted to evaluate the effect of organic manuring practices to improve the growth and yield of palak (Beta vulgaris var. bengalensis Hort.) during October 2015 - January 2016 and February 2016 - April, 2016 in the farmer's field located at Sandayagoundampalayam in Thondammutur block of Coimbatore district. The experiment was conducted with ten treatments and three replications. Of all the treatments the organic treatments of soil application with vermicompost $(4 \mathrm{t} / \mathrm{ha})+$ liquid nitrogen biofertilizer (Azospirullum 200ml/acre) + foliar spray of vermiwash (3\%) has shown the significant improvement in growth and yield parameters than other treatments. The treatment recorded the highest plant height $(46.69 \mathrm{~cm})$, number of leaves $(23.6)$, leaf length $(23.21 \mathrm{~cm})$, leaf width $(15.83 \mathrm{~cm})$, canopy spread in east-west $(47.09 \mathrm{~cm})$ and canopy spread north - south direction $(47.84 \mathrm{~cm})$ on 65 DAS over the control treatment and the yield parameters viz., fresh weight of leaves per plant(404.15 g), yield per plot $(13.15 \mathrm{~kg} / \mathrm{plot})$ and yield per hectare $(7732.87 \mathrm{~kg} / \mathrm{ha})$ and the lowest growth and yield characters were recorded by inorganic treatment of soil application with straight fertilizer at $100 \%$ RDF.

\section{Introduction}

Among different vegetable crops, leafy vegetables are quite high in their protective food value. They are important because of their successful and relatively easy cultivation as well as their high nutritive value, at a comparatively low cost. Palak or spinach beet (Beta vulgaris. Var. bengalensis) is one of the most popular leafy vegetables grown widely in India. Its tender soft succulent leaves are used as vegetable. Being the cheapest source of calcium, iron and phosphorus, it is valued much for its tender leaves. The continuous use of chemical fertilizers and pesticides in the cultivation of horticulture crops have caused decreased soil fertility physical and chemical properties of soil. Organics play a vital role in restoring the soil fertility and stabilizing crop productivity. Therefore, the application of plant nutrients through organic sources like FYM, vermicompost, biofertilizer along with different foliar spray remains the alternate choice for maintaining sustainable production. 
With an intention to increase the yield of greens, farmers are tempted to apply higher quantities of nitrogenous fertilizers, which may lead to accumulation of anti-nutrient factors in the greens beyond permissible limit. Hence, there is a need to substitute the inorganic nutrient requirements with organic nutrient sources to enhance the production of greens with lower content of anti-nutritional factors. With this background, the present study was undertaken in order to study the effect of organic manuring practices to improve the growth and yield of palak (Beta vulgaris var. bengalensis Hort.).

\section{Materials and Methods}

The experiment was conducted during October 2015 - January 2016 and February 2016 - April, 2016 in the farmer's field located at Sandayagoundampalayam in Thondammutur block of Coimbatore district. The design followed was RBD with ten treatments and three replications. The ten treatment combinations were $\mathrm{T}_{1}$ (soil application with farm yard manure (10t/ha) + liquid nitrogen biofertilizer (Azospirullum $200 \mathrm{ml} /$ acre $)+$ foliar spray of effective microorganisms (2\%)), $\mathrm{T}_{2}$ (soil application with farm yard manure (10t/ha) + liquid nitrogen biofertilizer (Azospirullum 200ml/ acre) + foliar spray of humic acid (3\%)), $\mathrm{T}_{3}$ (soil application with farm yard manure $(10 \mathrm{t} / \mathrm{ha})+$ liquid nitrogen biofertilizer (Azospirullum 200ml/acre) + foliar spray of vermiwash $(3 \%)$ ), $\mathrm{T}_{4}$ (soil application with vermicompost $(4 \mathrm{t} / \mathrm{ha})+$ liquid nitrogen biofertilizer (Azospirullum 200ml/acre) + foliar spray of effective microorganisms (2\%)), $\mathrm{T}_{5}$ (soil application with vermicompost $(4 \mathrm{t} / \mathrm{ha})+$ liquid nitrogen biofertilizer (Azospirullum 200ml/acre) + foliar spray of humic acid (3\%)), $\mathrm{T}_{6}$ (soil application with vermicompost (4t/ha) + liquid nitrogen biofertilizer (Azospirullum 200ml/acre) + foliar spray of vermiwash $(3 \%)$ ), $\mathrm{T}_{7}$ (soil application with farm yard manure (10t/ha) + soil application with vermicompost (4t/ha) + liquid nitrogen biofertilizer (Azospirullum $200 \mathrm{ml} / \mathrm{acre})+$ foliar spray of effective microorganisms (2\%)), $\mathrm{T}_{8}$ (soil application with farm yard manure (10t/ha) + soil application with vermicompost $(4 \mathrm{t} / \mathrm{ha})+$ liquid nitrogen biofertilizer (Azospirullum $200 \mathrm{ml} /$ acre $)+$ foliar spray of humic acid $(3 \%)), \mathrm{T}_{9}$ (soil application with farm yard manure (10t/ha) + soil application with vermicompost $(4 \mathrm{t} / \mathrm{ha})+$ liquid nitrogen biofertilizer (Azospirullum 200ml/acre) + foliar spray of vermiwash (3\%)) and $\mathrm{T}_{10}$ (control- soil application with straight fertilizers at $100 \% \mathrm{RDF}$ ).

The variety All Green was used as the test crop. As per the treatment vermicompost and farmyard manure were applied as soil basal application and the liquid nitrogen biofertilizer Azospirillum was applied as drip fertilizer at the rate of $200 \mathrm{ml} /$ acre. Vermiwash and humic acid were sprayed on 10,30,45 days after sowing each at 3 percent concentration where as effective microorganisms was applied on10,30,45 days after sowing at 2 percent concentration. The soil was brought to fine tilth and raised beds were formed at a spacing of $45 \mathrm{~cm}$. The gross size of an individual plot was $17 \mathrm{~m}^{2}$. The separate block of land was used for the inorganic control treatment. For control treatment the straight fertilizers were applied to the soil at the rate of $120: 60: 60 \mathrm{~kg}$ NPK $\mathrm{ha}^{-1}$. The same standard cultural practices were followed for both organic and inorganic plots but the plant protection measures for organic treatments were carried out by biopesticides whereas for inorganic control treatment inorganic pesticides were used. Harvesting of the fresh, tender, succulent leaves was done at 25, 45 and 65 days after sowing. Data on growth and yield parameters were recorded at 65 DAS and were statistically analyzed. 


\section{Results and Discussion}

\section{Plant height}

The organic treatments of soil application with vermicompost @4t/ha + liquid nitrogen biofertilizer (Azospirillum @ 200ml/acre) + foliar spray of vermiwash $(3 \%)\left(\mathrm{T}_{6}\right)$ recorded significantly highest crop mean plant height of $46.69 \mathrm{~cm}$ on 65DAS (Table 1). This might be due to the presence of large amount of humic substances in the vermicompost which might have improved the soil properties and increased the microbial activity of the soil and resulted in the release of nutrients. This is found to be in accordance with the findings of Abdullah Adil Ansari (2008) who stated that organic amendments like vermicompost and vermiwash promote humification, increased microbial activity and enzyme production, which, in turn, bring about the aggregate stability of soil particles, resulting in better aeration and they also has a property of binding mineral particles like calcium, magnesium and potassium in the form of colloids of humus and clay, facilitating stable aggregates of soil particles for desired porosity to sustain plant growth. Organic manure also enhances soil aggregation, aeration, water holding capacity and amended the root system by flow of nutrients which in combination creates favourable conditions for root respiration, nutrients absorption, root and upper parts growth (Hala Kandil, 2009). Increase in plant height due to vermicompost and vermiwash has been reported by several workers such as Jaya Sharma and Sunita Agarwal (2014) in spinach, Devan Elumalai (2013) in okra. The lowest plant height was recorded by the inorganic control treatment of soil application of straight fertilizers at $100 \%$ RDF. This might be due to slow release of nutrients due to reduced microbial activity in the soil. This finding is in accordance with Uday Sharma (2011) who stated that the inorganic fertilizers reduce the microbial activity of the soil.

\section{Number of leaves}

The treatment of soil application with vermicompost @ 4 tonnes/ha + liquid nitrogen biofertilizer (Azospirillum @ 200ml/acre) + foliar spray of vermiwash $(3 \%)\left(\mathrm{T}_{6}\right)$ recorded the highest mean number of leaves of 23.6 which was on par with treatment $\mathrm{T}_{5}$ (soil application with vermicompost (4t/ha)+liquid nitrogen biofertilizer (Azospirillum @ $200 \mathrm{ml} / \mathrm{acre})+$ foliar spray of humic acid (3\%) with mean values of 22.78 is given in table 1 .

The reason might be due to application of vermicompost since vermicompost supply most nutrients in the available form such as nitrates, phosphates, exchangeable calcium and soluble potassium and also plant growth regulating substances, necessary for plant growth parameters. This result is in agreement with the findings of Jadhav et al., 2014 in radish and Hemant Samadhiya (2013) in tomato Tafesse Kibatu and Meseret Mamo (2014) in beetroot, Abhilash (2012) in amaranthus, who stated that the application of vermicompost increases the plant growth promoting substances which results in the increase in number of leaves.

\section{Leaf length}

Among the different treatments, soil application with vermicompost @ 4 tonnes/ha + liquid nitrogen biofertilizer (Azospirillum $200 \mathrm{ml} / \mathrm{acre}$ ) + foliar spray of vermiwash $(3 \%)\left(\mathrm{T}_{6}\right)$ recorded the highest mean leaf length of $23.21 \mathrm{~cm}$ (Table 1). This might be due to the increased uptake of available major nutrients of the plant which results in the translocation of nutrients to the plant part. This is in accordance with the findings of Jadhav (2014) who reported that vermicompost influence plant growth directly via the supply of plant growth regulating substances (PGR) which results in the uptake of nutrients. Similar result was also given by 
Manoj Kumar (2014) in broccoli and Rao (2010) in onion.

\section{Leaf width}

The highest mean leaf width was recorded in the organic treatment $\mathrm{T}_{6}$ (soil application with vermicompost @ 4 tonnes/ha + liquid nitrogen biofertilizer (Azospirillum @ 200ml/acre) + foliar spray of vermiwash (3\%)) with $15.83 \mathrm{~cm}$ which was found to be on par with treatment $\mathrm{T}_{5}$ (soil application with vermicompost (4t/ha) + liquid nitrogen biofertilizer (Azospirillum $200 \mathrm{ml} /$ acre $)+$ foliar spray of humic acid (3\%)) (Table 2). This might be due to the continuous nutrient availability by the use of organics. This is found to be in accordance with findings of Mohammad Rezaul Hasan and Solaiman (2013) who reported that the use of organics in cauliflower results in the continuous availability of nutrients to the plants and increased the growth and development.

\section{Canopy spread}

The effect of different organic manures on canopy spread (East-West and North-South direction) of palak was recorded and pooled mean are furnished in the table 2 . The organic treatments had significant influence on canopy spread (north-south) over control in both the crops. Canopy spread (east-west) was found to be high in the organic treatment $\mathrm{T}_{6}$ (soil application with vermicompost @ 4 tonnes/ha + liquid nitrogen biofertilizer (Azospirillum @ $200 \mathrm{ml} /$ acre) + foliar spray of vermiwash (3\%) with mean value of $47.09 \mathrm{~cm}$. The highest mean canopy spread (north-south) was recorded in the organic treatment $\mathrm{T}_{6}$ (soil application with vermicompost @ 4 tonnes/ha + liquid nitrogen biofertilizer (Azospirillum @ $200 \mathrm{ml} / \mathrm{acre})+$ foliar spray of vermiwash (3\%) was $47.84 \mathrm{~cm}$. The increase in leaf length due to the increased uptake of nutrients might be the reason for increased plant spread in both direction. This is found to be in accordance with findings of Manoj Kumar and Bikash Das (2013) who stated that the application of vermicompost in broccoli increased the nutrient uptake of the plant resulting in increased plant growth characters.

\section{Yield parameters}

Among the various organic treatments the soil application with vermicompost @ 4 tonnes/ha + liquid nitrogen biofertilizer (Azospirillum @ $200 \mathrm{ml} /$ acre) + foliar spray of vermiwash (3\%) resulted in increased fresh weight of leaves per plant $(404.15 \mathrm{~g})$, yield per plot $(13.15 \mathrm{~kg} / \mathrm{plot})$ and yield per hectare $(7732.87 \mathrm{~kg} / \mathrm{ha})$ (Table 3). The increase in yield attributes might be due to the application of organic source of fertilizers viz., vermicompost, vermiwash, Azospirillum which increases the plant height, number of leaves per plant, leaf area, dry matter production and increased total chlorophyll content resulted in higher photosynthetic rate in plant leading to enhance the yield. The reason might also be due to the supply of liquid Azospirillum in rhizosphere creating favourable condition for Nfixation at higher rate and supply of other nutrients, bacterial secretion and hormone production and ultimately increased the yield. This result is found to be in accordance with Madhavi Latha and Veena Joshi (2013) in palak and amaranthus, who stated that the application of organics mainly biofertilizers attributed to better growth of plants and higher yields by slow release of nutrients for absorption with additional production of plant growth promoting substances like giberellin, cytokinin and auxins. Abdullah Adil Ansari(2007) observed that better growth of plants and higher yield in onion by slow release of nutrients for absorption with additional nutrients like giberellin, cytokinin and auxins, by the application of organic inputs like vermicompost in combination with vermiwash. 
Table.1 Effect of organic manures on the plant height $(\mathrm{cm})$, number of leaves and leaf length $(\mathrm{cm})$ of the Palak var. 'All Green'

\begin{tabular}{|c|c|c|c|c|c|c|c|c|c|}
\hline \multirow{2}{*}{ Treatments } & \multicolumn{3}{|c}{ Plant height $(\mathrm{cm})$} & \multicolumn{3}{c|}{ Number of leaves } & \multicolumn{3}{c|}{ Leaf length(cm) } \\
\cline { 2 - 10 } & Crop I & Crop II & Mean & Crop I & Crop II & Mean & Crop I & Crop II & Mean \\
\hline $\mathbf{T}_{\mathbf{1}}$ & 39.14 & 39.75 & 39.44 & 19 & 19.0 & 19.00 & 19.1 & 18.94 & 19.02 \\
\hline $\mathbf{T}_{\mathbf{2}}$ & 38.46 & 39.18 & 38.81 & 18.63 & 17.60 & 17.81 & 18.4 & 18.07 & 18.23 \\
\hline $\mathbf{T}_{\mathbf{3}}$ & 38.52 & 39.88 & 39.2 & 19.57 & 16.53 & 17.78 & 19.8 & 19.89 & 19.84 \\
\hline $\mathbf{T}_{\mathbf{4}}$ & 39.82 & 40.43 & 40.12 & 21.47 & 22.71 & 21.73 & 19.4 & 19.57 & 19.48 \\
\hline $\mathbf{T}_{\mathbf{5}}$ & 43.17 & 42.17 & 42.67 & 22.57 & 23.76 & 22.78 & 19.2 & 19.38 & 19.29 \\
\hline $\mathbf{T}_{\mathbf{6}}$ & 47.75 & 45.65 & 46.69 & 23.20 & 24.65 & 23.6 & 23.1 & 23.32 & 23.21 \\
\hline $\mathbf{T}_{\mathbf{7}}$ & 37.72 & 38.54 & 38.13 & 18.10 & 18.54 & 18.05 & 19.1 & 19.03 & 19.06 \\
\hline $\mathbf{T}_{\mathbf{8}}$ & 37.44 & 39.03 & 38.23 & 18.23 & 16.21 & 17.11 & 19.2 & 20.03 & 19.61 \\
\hline $\mathbf{T}_{\mathbf{9}}$ & 37.75 & 38.96 & 38.35 & 19.60 & 18.12 & 18.8 & 18.9 & 18.55 & 18.72 \\
\hline $\mathbf{T}_{\mathbf{1 0}}$ & 36.82 & 35.65 & 36.23 & 14.53 & 14.06 & 14.26 & 15.2 & 14.78 & 14.98 \\
\hline SEd & $\mathbf{1 . 0 5 5 7}$ & $\mathbf{0 . 0 8 8 5 0}$ & $\mathbf{0 . 9 7 4 1}$ & $\mathbf{0 . 4 0 6 0}$ & $\mathbf{0 . 3 8 3 0}$ & $\mathbf{0 . 3 9 4 7}$ & $\mathbf{0 . 4 7 6 0}$ & $\mathbf{0 . 4 6 4 3}$ & $\mathbf{0 . 4 7 0 2}$ \\
\hline $\mathrm{CD}(\mathbf{0 5 \%})$ & $\mathbf{2 . 2 1 7 1}$ & $\mathbf{1 . 8 5 8 6}$ & $\mathbf{1 . 9 5 8 0}$ & $\mathbf{0 . 8 5 2 5}$ & $\mathbf{0 . 8 0 4 3}$ & $\mathbf{0 . 7 9 3 3}$ & $\mathbf{0 . 9 9 9 7}$ & $\mathbf{0 . 9 7 5 1}$ & $\mathbf{0 . 9 4 5 1}$ \\
\hline
\end{tabular}

$\mathrm{T}_{1}$ - Soil application with FYM (10t/ha)+Liquid Nitrogen Biofertilizer (Azospirillum $200 \mathrm{ml} / \mathrm{acre})+$ Foliar spray of effective microorganisms $(2 \%)$

$\mathrm{T}_{2}$ - Soil application with FYM (10t/ha)+ Liquid Nitrogen Biofertilizer (Azospirillum 200ml/acre)+ Foliar spray of humic acid (3\%)

$\mathrm{T}_{3}$ - Soil application with FYM (10t/ha) + Liquid Nitrogen Biofertilizer (Azospirillum 200ml/acre)+ Foliar spray of vermiwash (3\%)

$\mathrm{T}_{4}$ - Soil application with Vermicompost (4t/ha)+ Liquid Nitrogen Biofertilizer (Azospirillum $200 \mathrm{ml} / \mathrm{acre})+$ Foliar spray of effective microorganisms $(2 \%)$
$\mathrm{T}_{5}$ - Soil application with Vermicompost (4t/ha)+ Liquid Nitrogen Biofertilizer (Azospirillum 200ml/acre)+ Foliar spray of humic acid(3\%)

$\mathrm{T}_{6}$ - Soil application with Vermicompost (4t/ha)+ Liquid Nitrogen Biofertilizer (Azospirillum 200ml/acre)+ Foliar spray of vermiwash (3\%)

$\mathrm{T}_{7}$ - Soil application with FYM $(10 \mathrm{t} / \mathrm{ha})+\mathrm{T}_{4}$

$\mathrm{T}_{8}$ - Soil application with FYM (10t/ha) $+\mathrm{T}_{5}$

$\mathrm{T}_{9}$ - Soil application with FYM (10t/ha) $+\mathrm{T}_{6}$

$\mathrm{T}_{10^{-}}$Soil application with straight fertilizers at $100 \% \mathrm{RDF}$. 
Table.2 Effect of organic manures on the leaf width $(\mathrm{cm})$ and canopy spread $(\mathrm{cm})$ of the Palak var. 'All Green'

\begin{tabular}{|c|c|c|c|c|c|c|c|c|c|}
\hline \multirow{2}{*}{ Treatments } & \multicolumn{3}{|c}{ Leaf width $(\mathbf{c m})$} & \multicolumn{3}{c|}{ Canopy spread (East-West) $(\mathbf{c m})$} & \multicolumn{3}{c|}{ Canopy spread (North-South) (cm) } \\
\cline { 2 - 11 } & Crop I & Crop II & Mean & Crop I & Crop II & Mean & Crop I & Crop II & Mean \\
\hline $\mathbf{T}_{\mathbf{1}}$ & 13.86 & 13.45 & 13.65 & 39.48 & 41 & 40.24 & CropI & CropII & Mean \\
\hline $\mathbf{T}_{\mathbf{2}}$ & 13.54 & 12.96 & 13.25 & 39.87 & 40.3 & 40.09 & 44.55 & 43.4 & 43.98 \\
\hline $\mathbf{T}_{\mathbf{3}}$ & 13.7 & 13.38 & 13.53 & 41.04 & 39.8 & 40.42 & 44.99 & 44.3 & 44.65 \\
\hline $\mathbf{T}_{\mathbf{4}}$ & 14.64 & 14.65 & 14.64 & 44.41 & 43.4 & 43.91 & 43.4 & 43.52 & 43.46 \\
\hline $\mathbf{T}_{\mathbf{5}}$ & 14.82 & 15.00 & 14.9 & 45.75 & 45.6 & 45.68 & 44.98 & 45.3 & 45.14 \\
\hline $\mathbf{T}_{\mathbf{6}}$ & 15.86 & 15.81 & 15.83 & 47.07 & 47.1 & 47.09 & 46.1 & 45.6 & 45.85 \\
\hline $\mathbf{T}_{\mathbf{7}}$ & 13.52 & 13.38 & 13.45 & 41.3 & 41.6 & 41.45 & 47.88 & 47.8 & 47.84 \\
\hline $\mathbf{T}_{\mathbf{8}}$ & 12.82 & 13.72 & 13.26 & 40.57 & 40.7 & 40.64 & 43.68 & 43.6 & 43.64 \\
\hline $\mathbf{T}_{\mathbf{9}}$ & 13.24 & 13.65 & 13.44 & 40.8 & 40.9 & 40.85 & 42.26 & 42.1 & 42.18 \\
\hline $\mathbf{T}_{\mathbf{1 0}}$ & 9.41 & 9.38 & 9.39 & 36.24 & 36.3 & 36.27 & 41.38 & 41.6 & 41.49 \\
\hline SEd & $\mathbf{0 . 3 2 2}$ & $\mathbf{0 . 2 4 9 3}$ & $\mathbf{0 . 2 8 8}$ & $\mathbf{0 . 7 9 4 0}$ & $\mathbf{1 . 0 2 3 9}$ & $\mathbf{0 . 9 1 6 2}$ & 37.42 & 37.8 & 37.61 \\
\hline $\mathrm{CD}(0.05 \%)$ & $\mathbf{0 . 6 7 7 2}$ & $\mathbf{0 . 5 2 3 4}$ & $\mathbf{0 . 5 7 9 3}$ & $\mathbf{1 . 6 6 7 4}$ & $\mathbf{2 . 1 5 0 2}$ & $\mathbf{1 . 8 4 1 6}$ & $\mathbf{0 . 8 2 2 0}$ & $\mathbf{1 . 5 8 4 0}$ & $\mathbf{0 . 7 8 8 9}$ \\
\hline
\end{tabular}

$\mathrm{T}_{1}$ - Soil application with FYM (10t/ha)+Liquid Nitrogen Biofertilizer (Azospirillum $200 \mathrm{ml} / \mathrm{acre})+$ Foliar spray of effective microorganisms $(2 \%)$

$\mathrm{T}_{2}$ - Soil application with FYM (10t/ha)+ Liquid Nitrogen Biofertilizer (Azospirillum 200ml/acre)+ Foliar spray of humic acid (3\%)

$\mathrm{T}_{3}$ - Soil application with FYM (10t/ha) + Liquid Nitrogen Biofertilizer (Azospirillum 200ml/acre)+ Foliar spray of vermiwash (3\%)

$\mathrm{T}_{4}$ - Soil application with Vermicompost (4t/ha)+ Liquid Nitrogen Biofertilizer (Azospirillum $200 \mathrm{ml} /$ acre) + Foliar spray of effective microorganisms(2\%)
$\mathrm{T}_{5}$ - Soil application with Vermicompost (4t/ha)+ Liquid Nitrogen Biofertilizer (Azospirillum 200ml/acre)+ Foliar spray of humic acid (3\%)

$\mathrm{T}_{6^{-}}$Soil application with Vermicompost (4t/ha)+ Liquid Nitrogen Biofertilizer (Azospirillum 200ml/acre)+ Foliar spray of vermiwash (3\%)

$\mathrm{T}_{7}$ - Soil application with FYM (10t/ha) $+\mathrm{T}_{4}$

$\mathrm{T}_{8}$ - Soil application with FYM (10t/ha) $+\mathrm{T}_{5}$

$\mathrm{T}_{9^{-}}$Soil application with FYM (10t/ha) $+\mathrm{T}_{6}$

$\mathrm{T}_{10}$ - Soil application with straight fertilizers at $100 \% \mathrm{RDF}$. 
Table.3 Effect of organic manures on the yield per plot (kg/plot) and yield per hectare $(\mathrm{kg} / \mathrm{ha})$ and fresh weight of leaves (g) at different growth stages of Palak var. 'All Green'

\begin{tabular}{|c|c|c|c|c|c|c|c|c|c|}
\hline \multirow{2}{*}{ Treatments } & \multicolumn{2}{|c|}{ Fresh weight of leaves $(\mathrm{g})$} & \multicolumn{3}{|c|}{ Yield per plot $(\mathrm{kg})$} & \multicolumn{2}{c|}{ Yield per ha (kg/ha) } \\
\cline { 2 - 9 } & Crop I & Crop II & Mean & Crop I & Crop II & Mean & Crop I & Crop II & Mean \\
\hline $\mathbf{T}_{\mathbf{1}}$ & 300.24 & 350.10 & 325.56 & 9.89 & 9.80 & 9.84 & 5745. & 5764.68 & 5754.87 \\
\hline $\mathbf{T}_{\mathbf{2}}$ & 339.67 & 367.26 & 353.29 & 10.17 & 9.91 & 10.04 & 5977.83 & 6046.97 & 6012.39 \\
\hline $\mathbf{T}_{\mathbf{3}}$ & 345.48 & 336.27 & 340.80 & 9.96 & 9.83 & 9.89 & 5899.86 & 6088.60 & 5994.22 \\
\hline $\mathbf{T}_{\mathbf{4}}$ & 367.48 & 355.28 & 361.38 & 10.82 & 10.58 & 10.69 & 6334.18 & 6381.40 & 6357.79 \\
\hline $\mathbf{T}_{\mathbf{5}}$ & 366.36 & 381.25 & 373.80 & 11.69 & 11.64 & 11.66 & 6831.25 & 6802.69 & 6816.97 \\
\hline $\mathbf{T}_{\mathbf{6}}$ & 398.12 & 410.17 & 404.15 & 12.96 & 13.35 & 13.15 & 7745.62 & 7720.14 & 7732.87 \\
\hline $\mathbf{T}_{\mathbf{7}}$ & 323.27 & 341.26 & 332.27 & 9.61 & 9.36 & 9.48 & 5763.75 & 5746.66 & 5755.20 \\
\hline $\mathbf{T}_{\mathbf{8}}$ & 356.38 & 342.18 & 349.28 & 9.53 & 9.20 & 9.36 & 5565.91 & 5564.06 & 5564.98 \\
\hline $\mathbf{T}_{\mathbf{9}}$ & 344.34 & 349.25 & 346.80 & 9.74 & 9.73 & 9.73 & 5707.78 & 5684.01 & 5695.89 \\
\hline $\mathbf{T}_{\mathbf{1 0}}$ & 298.23 & 311.13 & 304.68 & 8.03 & 8.06 & 8.04 & 4757.64 & 4895.46 & 4826.54 \\
\hline $\mathrm{SEd}$ & $\mathbf{1 0 . 6 6}$ & $\mathbf{1 1 . 6 8}$ & $\mathbf{1 0 . 6 7}$ & $\mathbf{0 . 1 7 9 9}$ & $\mathbf{0 . 2 0 5 7}$ & $\mathbf{0 . 1 9 3 2}$ & $\mathbf{7 5 . 3 9 1}$ & $\mathbf{1 1 4 . 3 3 2}$ & $\mathbf{9 6 . 8 3 9}$ \\
\hline $\mathrm{CD}(0.05 \%)$ & $\mathbf{2 1 . 7 8}$ & $\mathbf{2 3 . 2 5}$ & $\mathbf{2 1 . 4 3}$ & $\mathbf{0 . 3 7 7 8}$ & $\mathbf{0 . 4 3 1 9}$ & $\mathbf{0 . 2 8 8 4}$ & $\mathbf{1 5 8 . 3 2 9}$ & $\mathbf{2 4 0 . 0 9 7}$ & $\mathbf{1 9 4 . 6 4 7}$ \\
\hline
\end{tabular}

$\mathrm{T}_{1}$ - Soil application with FYM (10t/ha)+Liquid Nitrogen Biofertilizer

(Azospirillum $200 \mathrm{ml} / \mathrm{acre})+$ Foliar spray of effective microorganisms $(2 \%)$

$\mathrm{T}_{2}$ - Soil application with FYM (10t/ha)+ Liquid Nitrogen Biofertilizer

$$
\text { (Azospirillum 200ml/acre)+ Foliar spray of humic acid (3\%) }
$$

$\mathrm{T}_{3}$ - Soil application with FYM (10t/ha) + Liquid Nitrogen Biofertilizer (Azospirillum 200ml/acre)+ Foliar spray of vermiwash (3\%)

$\mathrm{T}_{4}$ - Soil application with Vermicompost (4t/ha)+ Liquid Nitrogen Biofertilizer (Azospirillum $200 \mathrm{ml} / \mathrm{acre})+$ Foliar spray of effective microorganisms $(2 \%)$
$\mathrm{T}_{5}$ - Soil application with Vermicompost (4t/ha)+ Liquid Nitrogen Biofertilizer (Azospirillum 200ml/acre)+ Foliar spray of humic acid (3\%)

$\mathrm{T}_{6}$ - Soil application with Vermicompost (4t/ha)+ Liquid Nitrogen Biofertilizer (Azospirillum 200ml/acre)+ Foliar spray of vermiwash (3\%)

$\mathrm{T}_{7^{-}}$Soil application with FYM $(10 \mathrm{t} / \mathrm{ha})+\mathrm{T}_{4}$

$\mathrm{T}_{8^{-}}$Soil application with FYM (10t/ha) $+\mathrm{T}_{5}$

$\mathrm{T}_{9}$ - Soil application with FYM (10t/ha) $+\mathrm{T}_{6}$

$\mathrm{T}_{10^{-}}$Soil application with straight fertilizers at $100 \% \mathrm{RDF}$. 
Kibatu and Meseret Mamo (2014) observed increased yield in beetroot due to the application of vermicompost and stated that the yield increase might be due to the improved physical, chemical and biological properties of the soil with high levels of total and available nitrogen, phosphorous, potassium, micro nutrients microbial and enzyme activities and growth regulators by vermicompost.

In conclusion, the growth and yield characters viz., plant height, number of leaves, leaf length, leaf width, canopy spread, fresh weight of leaves per plant, yield per plot, yield per hectare were found to be highest in the organic treatments soil application with vermicompost (4t/ha) + liquid nitrogen biofertilizer (Azospirullum 200ml/acre) + foliar spray of vermiwash (3\%). The lowest growth and yield parameters were observed in the inorganic treatment of soil application with straight fertilizers at $100 \%$ RDF. This findings showed that the organics along with biofertilizers increases the bioavailability of all the nutrients to the plant thereby increases the yield.

\section{References}

Abdul A.A. 2008. Effect of vermicompost and vermiwash on the productivity of spinach (Spinacia oleracea), onion (Allium cepa) and potato (Solanum tuberosum). World J. Agric. Sci., 4(5): 554-557.

Abhilash, Aswathi and P.P. Sheeja. 2013. Influence of organic manures and biofertilizers on the yield of Amaranthus dubius. Asia Pacific J.f Environ. Eco. Sustain. Develpo., 28: 26-28..

Devan E.2013. Influence of vermiwash and plant growth regulators on the exomorphological characters of Abelmoschus esculentus (Linn.)
Moench. African J. of Basic \& Applied Sci., 5(2): 82-90.

Hasan, M.R. and H.M Solaiman 2012. Efficacy of organic and organic fertilizer on the growth of Brassica oleracea L. (Cabbage). International J. Agric Crop Sci, 5(7):34-43

Hemanth Samadhiya and P. Dandotiya. 2013. Effect of vermiwash on the growth and development of leaves and stem of tomato plants. International $\mathbf{J}$. Curr. Res., 4(6): 3-6.

Jadhav, P, D. J Patel, A. Kireeti, N. B Patil, S. S Dekhane, and N. B Harad. 2014. Effect of different levels of vermicompost on growth and yield of radish cv. local variety. International J. Information Research and Review, 1(2): $29-31$.

Jaya Sharma and A. Sunita. 2014. Impact of organic fertilizers on growth, yield and quality of spinach. Indian J. Plnt Sci, 3 (3): 37-43.

Kibatu, Tafesse and M. Mamo. 2014. Vermicompost and vermiwash on growth, yield and yield components of beetroot (Beta vulgaris L.).World Applied Sci J., 32 (2): 177182.

Madavi Latha and J. Veena. 2013. Performance of organic leafy vegetables production under Hyderabad conditions. Veg. Sci., 40 (2): 243-245

Manoj Kumar, D. Bikash, K. K Prasad and Prashant Kumar. 2013. Effect of integrated nutrient management on growth and yield of broccoli (Brassica oleracea var. italica) under Jharkhand conditions. Veg. Sci., 4: 117-120.

Masarirambi MT, M.M, Oseni O.T. Sibiya. 2010. Effects of organic fertilizers on growth, yield quality and sensory evaluation of red lettuce (Lactuca 
sativa L) 'Veneza Roxa'. Agric and Biol. J. North America., 1(6): 1319-1324.

Mohammad Rezaul. H and Solaiman.2013. Efficacy of organic and organic fertilizer on the growth of Brassica oleracea L. (Cabbage). Indian J. Horti., 2: 21-32

Rao K.R, C. Mushan, A.C. Mulani and G.Y.Parlekar.2010. Effect of vermicompost on the growth and yield of onion (Allium cepa). Karnataka J. Agric. Sci., 23 (2): 361363

Siddappa, R. and N.K. Hegde. 2011. Effect of foliar spray of vermiwash and nutritional treatments on growth and yield performance of curry leaf var. Suvasini. The Asian J. Horti., 6(1): 6870

Uday Sharma and K.U. Jitender. 2011. Influence of integrated use of inorganic and organic sources of nutrients on growth and production of pea. J. Farm Sci., 1(1): 14 -18.

Tafesse Kibatu and Meseret Mamo.2012. Vermicompost and Vermiwash on Growth, Yield and Yield Components of cabbage. Acta Hortic., 32(2): 177182.

\section{How to cite this article:}

Irene Vethamoni, P. and Syama S. Thampi. 2018. Effect of Organic Manuring Practices on Growth and Yield of Palak (Beta vulgaris var. bengalensis Hort.). Int.J.Curr.Microbiol.App.Sci. 7(08): 1855-1863. doi: https://doi.org/10.20546/ijcmas.2018.708.213 